\section{Graft Angle and Its Relationship to Tomato Plant Survival}

\author{
Michael G. Bausher ${ }^{1}$ \\ USDA-ARS, U.S. Horticultural Research Laboratory, 2001 South Rock Road, \\ Fort Pierce, FL 34945
}

Additional index words. Solanum lycopersicum, robotics, manual grafting, pull force, rootstocks

\begin{abstract}
Growing transplants that can withstand the rigors of open-field production is imperative for the successful adoption of grafting in large-scale commercial fields and especially for those who seek to adopt this technology as an alternative to soil fumigation. This study examines the relationship of tensile strength to graft angle and plant survival. Tomato (Solanum lycopersicum) seedlings of 'FL-47' and 'Rutgers' were used as scions on 'Roma' rootstock under greenhouse and healing chamber conditions. Scions were grafted at angles of $20^{\circ}, 45^{\circ}$, and $70^{\circ}$. After a period of 10 days, the plants were severed near ground level and subjected to pull force analysis. Pull force of the graft increased significantly with the increased graft angle. Pull force between the $20^{\circ}$ vs. $70^{\circ}$ angles increased significantly as well as those of $45^{\circ}$ vs. $70^{\circ}$ grafts $(P \leq 0.001)$. Increase in graft angle resulted in greater survival of grafted plants from $79 \%\left(20^{\circ}\right), 81 \%\left(45^{\circ}\right)$, and $92 \%$ $\left(70^{\circ}\right)$. Fifteen commercial rootstocks grafted at $70^{\circ}$ had survival percentage rates between $\mathbf{9 7 \%}$ and $100 \%$. These studies demonstrate that the angle can significantly impact graft integrity and plant survival.
\end{abstract}

Growing vegetable plants for open-field production requires a plant that can withstand environmental challenges such as heavy rains, wind, and stressful temperatures. Obviously, the strength of the graft union is very important to the survival of the young grafted plant. Plants placed in the field as seedlings are dependent on the ability to survive the first week in the soil and establish an anchoring root system that can absorb water and nutrients. Open-field production of fresh-market tomatoes is reliant on transplants that are produced as plugs. As a result of the expense of growing these seedlings and the goal of hitting markets at prescribed times, growers contract with transplant producers to produce plants throughout the growing season. Plant losses during grafted transplant production can occur as a result of disease, environmental conditions, and mechanical damage. This process requires precise scheduling and weather can delay planting dates. Varieties are selected for horticultural characteristics that coincide with disease and market demand. Although aggressive breeding practices are being adopted to include all the desired resistance and

Received for publication 12 Apr. 2012. Accepted for publication 10 Aug. 2012.

Partial funding provided by USDA NIFA Grant 2011-51181-30963.

I thank various donors of seed listed in this article and members of the USHRL staff that assisted me in this work.

Mention of trade names or commercial products in this article is solely for the purpose of providing specific information and does not imply recommendation or endorsement by the U.S. Department of Agriculture.

${ }^{1}$ To whom reprint requests should be addressed; e-mail michael.bausher@ars.usda.gov. horticultural characteristics in one package, it is a difficult task as a result of linkage drag (Scott and Gardner, 2007). In addition, the decreased use of methyl bromide has forced growers to use alternatives such as grafted plants to manage soilborne pests and pathogens.

During the process of grafting, the scion can be selected for horticultural characteristics such as fruit quality, yield, and disease resistance. Also, rootstocks can be selected for soilborne disease, nematode resistance, and root vigor, all found in open-field conditions. The term open field means plants exposed to the natural environment with no protective shelter. Growing tomatoes in the southern United States often means plants must tolerate increased wind velocity and heavy rain events that can damage young plants. Also, open-field fresh tomatoes may be grown on plastic mulch, which can raise soil temperatures that may increase plant stress. Most of the information published thus far is related to plants grown under sheltered conditions (Kubota et al., 2008; Louws et al., 2010) and focuses on the viability of the technology. Limited literature addresses the reasons for choosing one grafting technique over another. Grafted plants used in open-field production require a grafting technique that can efficiently produce large quantities of plants that can survive in exposed fields. Little is known about the effect of grafting techniques on the physical attributes of the tomato seedling and plant survival or graft union integrity (Lee et al., 2010; Oda et al., 1994). The objectives of the study are to explore the effects of graft angle on plant survivability and graft union integrity.

\section{Materials and Methods}

Plant material and growing conditions. All experiments were conducted in greenhouses at the USDA-ARS Horticultural Research Laboratory facility, Fort Pierce, FL (lat. $27.41^{\circ} \mathrm{N}$, long. $80.35^{\circ} \mathrm{W}$ ) and nearby fields during 2010-11. All grafting experiments were carried out on tomato (Solanum lycopersicum L.) or interspecific rootstocks. Plants were seeded in rigid plastic plug trays with a cell volume of $27 \mathrm{~mL}$ and tray density of 242 plants. The planting media consisted of Premier Organic mixture (Premier Horticulture, Quakertown, PA). Both the rootstock and scion seed were planted on the same date and germinated under greenhouse conditions. At 21 to $31 \mathrm{~d}$ after sowing, the plants were grafted manually using the splice grafting technique (Oda, 1999) and held in place by silicon grafting clips (Bato Plastics, The Netherlands). The scions and rootstocks were cut in a simultaneous manner by placing the rootstock with the roots intact alongside a severed scion piece to match stem widths. A single-edge razor blade (American Safety Razor, Cedar Knolls, NJ) is then drawn across the two stems at the appropriate angle and both stems are severed simultaneously. The appropriate angle of cutting each rootstock scion was maintained by using a drawn template constructed for each of the appropriate severing angles. The rootstock and scion were then joined with a grafting clip; gentle pressure on the rootstock and scion was used to ensure intimate contact between both cut surfaces. The grafts were accomplished in this manner at angles of $20^{\circ}, 45^{\circ}$, and $70^{\circ}$. The finished grafted seedlings were then placed in a chamber to allow the plants to heal at conditions of $29{ }^{\circ} \mathrm{C}$ and $90 \%$ or greater humidity and light levels of $\approx 100$ $\mu \mathrm{mol} \cdot \mathrm{m}^{-2} \cdot \mathrm{s}^{-1}$ photosynthetic active radiation by cool white fluorescent light with illumination at $12 \mathrm{~h}$ per day. The plants were then allowed to heal for up to $7 \mathrm{~d}$ and placed in a greenhouse for $\approx 3 \mathrm{~d}$ before testing the strength of the graft unions using a pull force gauge. Each planted tray contained randomized blocks of the grafted plants for each graft angle.

Experiments. Experimental Group 1 (Table 1) used 'Rutgers' as a scion and 'Roma' as a rootstock (Siegers Seed, Holland, MI). These experiments were carried out during the months of Jan. 2011, Feb. 2011, and Mar. 2011 and repeated three times during each time period using 100 plants per graft angle or 300 plants per repetition for a total of 900 plants. Experimental Group 2 used scion 'FL47' with 'Roma' rootstock during Aug. 2011 and are listed in Table 2. A third experiment was carried out based on the results of Experimental Groups 1 and 2. The $70^{\circ}$ angle was used to test the overall survival of commercial rootstocks placed in the field. The rootstocks chosen were all commercial F1 hybrids or self-grafted scions. In Experimental Group 3, 'FL-91' was grafted on 15 commercial rootstocks listed in Table 3.

Pull force gauge. Pull force measurements were performed using a Wagner Instruments digital pull force gauge (Greenwich, CT) using the grafted plants at different times at $\approx 10 \mathrm{~d}$ after grafting. In each case, surviving plants 
for each graft angle were severed $\approx 1 \mathrm{~cm}$ from the soil surface. The severed base was placed in a cam lock device to hold the plant in place until downward pressure was applied by manual force. At the point of graft union failure, the device registers the amount of force in newtons (N) necessary to separate the graft. The sampling was repeated for each graft angle at each of four dates over an eight-month period. In all, 12 pull force trials were recorded.

Environmental measurements. In lieu of greenhouse temperature ranges, growing degree-days (GDDs) were calculated for each growing period using the formula (maximum

Table 1. Results of pull force in newtons (N) necessary to separate graft unions 'Rutgers' scion and 'Roma' rootstock at different times of the year in Experimental Group 1 with $20^{\circ}$, $45^{\circ}$, and $70^{\circ}$ graft treatments.

\begin{tabular}{lc}
\hline $\mathrm{PD}^{\mathrm{z}} 1$ (Jan. 2011) & \multicolumn{1}{c}{$\mathrm{R}^{\mathrm{y}} 1$} \\
\cline { 1 - 1 } Treatments & $\mathrm{Mean}^{\mathrm{v}} \pm \mathrm{SE}(\mathrm{N})$ \\
\hline Rutgers/Roma ${ }^{\mathrm{x}} 20^{\circ}$ & $2.52 \pm 0.28$ \\
Rutgers/Roma $45^{\circ}$ & $4.37 \pm 0.24$ \\
Rutgers/Roma $70^{\circ}$ & $7.64 \pm 0.34$ \\
Dunn's test & \\
& $20^{\circ}$ vs. $70^{\circ} * * *$ \\
& $20^{\circ}$ vs. $45^{\circ} * * *$ \\
$45^{\circ}$ vs. $70^{\circ * * *}$
\end{tabular}

$\mathrm{GDD}^{\mathrm{u}} 881$
PD 2 (Feb. 2011)

Rutgers/Roma $20^{\circ}$

Rutgers/Roma $45^{\circ}$

Rutgers/Roma $70^{\circ}$

Dunn's test

GDD $^{\text {u }} 912$

PD 3 (Mar. 2011)

Rutgers/Roma $20^{\circ}$

Rutgers/Roma $45^{\circ}$

Rutgers/Roma $70^{\circ}$

Dunn's test

$\mathrm{GDD}^{\mathrm{u}} 860$

\section{${ }^{\text {zPlanting date }}$}

${ }^{y}$ Separate experiments each angle treatment date consisting of 300 plants, 100 per replication.

x'Rutgers' scion/“Roma' rootstock.

${ }^{\mathrm{w}}$ Comparison of mean values of pull force $(\mathrm{PF})$ in $\mathrm{N}$; Kruskal-Wallis non-parametric test using Dunn's test for ranked data for each graft treatment probability was $P \leq 0.001$ (***) for both procedures.

${ }^{\mathrm{v}}$ Calculated mean values with SEM.

${ }^{\mathrm{u}} \mathrm{GDD}=$ growing degree-days .

Table 2. Pull force values of plants in Experimental Group 2 using 'FL-47' as the scion and 'Roma' rootstock.

\begin{tabular}{|c|c|c|c|}
\hline PD Aug. 2011 & R1 PF $(\mathrm{N})^{\mathrm{z}}$ & $\mathrm{R} 2$ & R3 \\
\hline Treatments & $(\text { mean } \pm \mathrm{SE})^{\mathrm{y}}$ & $($ mean $\pm \mathrm{SE})$ & $($ mean $\pm \mathrm{SE})$ \\
\hline$\overline{\text { FL-47/Roma } 20^{\circ}}$ & $3.41 \pm 0.69 \mathrm{a}^{\mathrm{x}}$ & $2.71 \pm 0.26 \mathrm{a}$ & $2.58 \pm 0.30 \mathrm{a}$ \\
\hline FL-47/Roma $45^{\circ}$ & $5.43 \pm 0.51 \mathrm{~b}$ & $3.87 \pm 0.64 \mathrm{a}$ & $4.22 \pm 0.57 \mathrm{~b}$ \\
\hline FL-47/Roma $70^{\circ}$ & $\begin{array}{c}9.94 \pm 0.70 \mathrm{c} \\
P<0.001^{\mathrm{v}}\end{array}$ & $\begin{array}{c}9.35 \pm 0.59 \mathrm{~b} \\
P<0.001\end{array}$ & $\begin{array}{c}10.31 \pm 0.53 \mathrm{c} \\
P<0.001\end{array}$ \\
\hline
\end{tabular}

${ }^{\text {R}}$ 1 to R3 are separate experiments each with 26 replicate plants per graft angle treatment with 'FL-47' scion and 'Roma' rootstock.

${ }^{y}$ Means of 26 replicate plants.

${ }^{\mathrm{x}}$ One-way analysis of variance; letter difference indicates significant pairwise differences between treatments in a column by the Holm-Sidak method $(\alpha=0.05)$

${ }^{\mathrm{w}} \mathrm{GDD}=$ growing degree-days

"Probability. $\left.a^{*} b\right)$ where $a$ is the radius of the long side and $\mathrm{b}$ is the short side of the ellipse. The long side value was calculated using the adjacent angle of the cut and the width of the stem.

\section{Results and Discussion}

Graft angle had a significant effect based on pull force (PF) in all of the experiments $(P \leq 0.001)$ as shown in Table 1 . There was no significant interaction between the individual replications within a scion combination and the data pooled. The $20^{\circ}$ angle recorded the least resistance and $70^{\circ}$ the highest. There was significant difference in the PF of the $20^{\circ}$ vs. $70^{\circ}$ for all the dates tested for 'Rutgers' Experimental Group 1. The same is true for the $20^{\circ}$ vs. $45^{\circ}$ and the $45^{\circ}$ vs. $70^{\circ}(P \leq 0.001)$ over all experiments in Group 1. The highest values for all dates were found during Mar. 2011 where the difference in PF between the $20^{\circ}$ and $70^{\circ}$ angles was 2.7 -fold. Clearly the increase in graft angle had a positive effect on $\mathrm{PF}$. The overall performance of another scion,
$\mathrm{T}^{\circ} \mathrm{C}+$ minimum $\mathrm{T}^{\circ} \mathrm{C}$ ) $/ 2$ to $10{ }^{\circ} \mathrm{C}$ (threshold $\mathrm{T}$ used) (McMaster and Wilhelm, 1997). The calculated GDDs are listed with the individual experiments. The calculated GDDs were not statistically different $(P \leq 0.667)$ for any of the growing periods listed.

Statistical methods. Statistical analysis consisted of a number of methods depending on the data set. The Kruskal-Wallis data rank procedure, a non-parametric test, using Sigma Stat 3.5 (Systat Software, Inc., Richmond, A), and the Dunn's test for the pull force were used when the data normality test failed (Elliot, 2011; Kruskal and Wallis, 1952). If performed with mean separations using the Holms-Sidak test. Grafted plant survival was calculated using the Cochran-Armitage nonparametric test for trend (SAS 9.2.3, Cary, NC). The data for survival was binomial with " 1 " representing survival and " 0 " not. The experimental design is one factor at three levels $\left(20^{\circ}, 45^{\circ}\right.$, and $70^{\circ}$ angles) completely randomized with two response variables: pull force and plant survival.

Calculations of cut surface area. The area of the ellipse made by the cut surface of the graft at different angles was calculated using the formula based on the area of a circle $(\pi$

HortScience Vol. 48(1) January 2013
'FL-47' (Experimental Group 2), produced similar results with $\mathrm{PF}$ differing significantly $(P \leq 0.001)$ between $20^{\circ}$ and $45^{\circ}$ in all but the second experiment and $20^{\circ}$ to $70^{\circ}$ grafts in all three experiments (Table 2). In this experimental group, again the $70^{\circ}$ graft angle produced the greatest $\mathrm{PF}$ values of $9.94 \mathrm{~N}, 9.35 \mathrm{~N}$, and $10.31 \mathrm{~N}$ for the three experiments, respectively, a 4-fold increase from the $20^{\circ}$ graft in the third experiment.

The increased resistance in PF as the graft angle increases may be the result of a larger surface area in contact between the scion and rootstock. The surface area of the $20^{\circ}$ graft was $5.22 \mathrm{~mm}^{2}$, the $45^{\circ}$ cut was $6.94 \mathrm{~mm}^{2}$, and $14.55 \mathrm{~mm}^{2}$ for the $70^{\circ}$ graft, respectively. As an example, the increase in surface area between the $45^{\circ}$ and $70^{\circ}$ graft is an increase of $210 \%$ between the two. The larger area may increase the amount of callus tissue formed in bridging the void and allow for cellular products to move from rootstock to scion increasing tensile strength of the graft union and may influence the ability of plants to withstand physical damage. One of the few studies that used tensile strength to determine graft compatibility-incompatibility was performed by Moore $(1981,1983)$ in a series of descriptive papers. He found the tensile strength of compatible Allegany stonecrop Hylotelephium telephoides (Michx.) H. Ohba (Sedum telephoides) grafts increased 2-fold for the first $2 \mathrm{~d}$ after grafting and 28-fold between the third and 11th day. Moore describes the regrowth of the cut cells as the "interdigitation" of callus cells, which is part of the process of wound healing, thus increasing the overall PF necessary to separate the graft (Moore and Walker, 1981). The increase in surface area from $45^{\circ}$ to $70^{\circ}$ was 2.10 -fold that of the $45^{\circ}$ angle. The pull force of the $70^{\circ}$ to $20^{\circ}$ graft is not directly proportional to the area of the graft union but the trend is greater adhesion strength with increased graft surface area. As shown in Table 2 , the significant mean pull force increase was near 4-fold between the $20^{\circ}$ and $70^{\circ}$ graft angle using 'FL-47' as the scion.

Survival of the grafted plants is significantly correlated with the increase in graft angle by Cochran-Armitage test for trend $(P \leq 0.001)$. The survival rate was $79 \%$, $81 \%$, and $92 \%$ for the $20^{\circ}, 45^{\circ}$, and $70^{\circ}$ grafts overall the studies, respectively, as shown in Figure 1. Increases in survival rate are important because grafting is labor-intensive and losses resulting from graft failure can represent significant economic loss. In a series of experiments, $70^{\circ}$ angle grafting was used and survival recorded for 15 different rootstocks or self-grafted rooted scions. As shown in Table 3 , there was a high rate of survival with all of the rootstocks used with 'FL-91' as the scion. There was no difference in seedling survival rate for any of the rootstocks used with all the survival rates between $97 \%$ and $100 \%$. Grafting at the $70^{\circ}$ angle has an added advantage in that individuals using this technique find that positioning the scion and rootstock by this method requires less effort because the greater angle 
Table 3. Survival percentage results of grafting 'FL-91'.

\begin{tabular}{|c|c|c|}
\hline Rootstock & Survival percent ${ }^{\mathrm{y}}$ & Source \\
\hline$\overline{\mathrm{BHN}} 833$ & 98 & BHN Seed, Immokalee, FL \\
\hline Sebring & 97 & Rogers/Syngenta, Boise,ID \\
\hline Big Power & 97 & Rijz Zwaan, Salinas, CA \\
\hline Imperial 643 & 100 & Enza Zaden, Salinas. CA \\
\hline H-4997 & 100 & Rick Center, Riverside, CA \\
\hline Maxifort & 100 & De Ruiter, Lakewood, CO \\
\hline Multifort & 99 & De Ruiter, Lakewood, CO \\
\hline Body & 99 & Seminis Vegetable Seed, Tifton, GA \\
\hline Florida 91 & 100 & Seminis Vegetable Seed, Tifton, GA \\
\hline Cheong Gang & 100 & Seminis Vegetable Seed, Tifton, GA \\
\hline Aloha & 100 & American Takii, Salinas, CA \\
\hline Anchor-T & 98 & American Takii, Salinas, CA \\
\hline $\mathrm{BB}$ & 97 & American Takii, Salinas, CA \\
\hline Camel & 100 & American Takii, Salinas, CA \\
\hline Vigostar 12 & 98 & Hazera Seeds, Coconut Creek, FL \\
\hline
\end{tabular}

\section{Trend of Graft Angle and Survival}

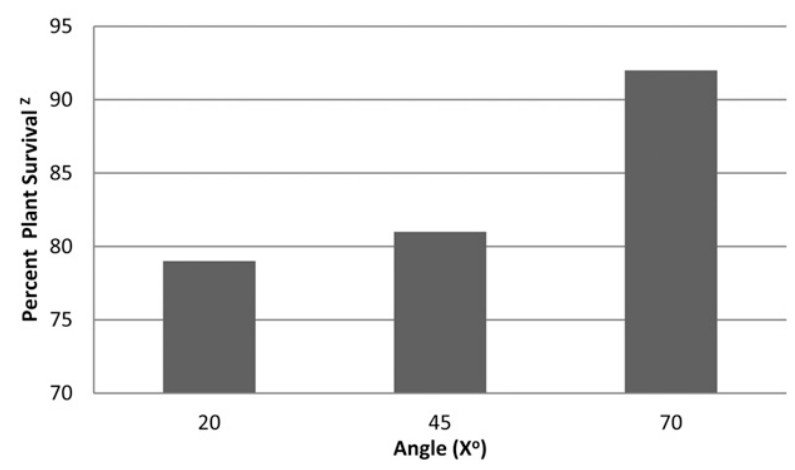

Fig. 1. Overall survival of grafts with 'Rutgers' and 'FL-47' as scions and 'Roma' rootstock by graft angle. ${ }^{\mathrm{z}}$ Cochran-Armitage test for trend $P<0.001$, non-parametric test.

self-aligns in the grafting clip. This results in few misalignments and subsequent graft failure. In all the tests performed, graft failure was probably caused by the lack of cellular activity to seal the graft wounds as a result of misalignment. In most cases, grafting was performed by individuals without significant experience in grafting.

\section{Summary and Conclusions}

These data show that grafts made at $70^{\circ}$ result in fewer graft failures and greater PF measurements of the finished grafts as a result of increased graft tensile strength. Survival rates were greater than $97 \%$ in commercial rootstocks including 'Aloha', 'Anchor-T', 'BB', 'Big Power', 'Body', 'Camel', 'Cheong Gang', 'Imperial 643', 'Multifort', 'Maxifort', 'Vigostar 12', 'BHN 833', H-7997, 'FL-91', and 'Sebring' when the $70^{\circ}$ graft angle is used. The high survival rates for $70^{\circ}$ grafted plants is economically beneficial in producing plants to meet demand and reducing replants in the field. The higher tensile strength has horticultural significance in that it improves the ability of plants to survive under adverse conditions during the first critical 2 weeks of planting when the plant is establishing itself in the field. Higher tensile is also necessary for commercial planting using mechanical planters in which the graft union can be subjected to adverse physical forces to avoid graft failure. This research finding can be used by commercial growers, small farmers, and homeowners using both conventional and organic practices to improve plant survival while simultaneously reducing plant cost.

\section{Literature Cited}

Elliot, A.C. 2011. A SAS macro implementation of a multiple comparison post hoc test for a Kruskal-Wallis analysis. Comput. Methods Programs Biomed. 102:75-80.

Kruskal, W. and W.A. Wallis. 1952. Use of ranks in one-criterion variance analysis. J. Amer. Stat. Assoc. 47:583-621.

Kubota, C., M.A. McClure, N. Kokalis-Burelle, M.G. Bausher, and E.N. Rosskopf. 2008. Vegetable grafting: History, use, and current technology status in North America. HortScience 43:1664-1669.

Lee, J., C. Kubota, S.J. Tsao, Z. Bie, P. Hoyos Echevarria, L. Morra, and M. Oda. 2010. Current status of vegetable grafting: Diffusion, grafting techniques, automation. Scientia Horticulturae (Amsterdam) 127:93-105.

Louws, F.J., C.L. Rivard, and C. Kubota. 2010. Grafting fruiting vegetables to manage soilborne pathogens, foliar pathogens, arthropods and weeds. Scientia Horticulturae (Amsterdam) 127: 127-146.

McMaster, G.S. and W.W. Wilhelm. 1997. Growing degree-days: One equation, two interpretation. Agr. For. Meteorol. 44:131-140.

Moore, R. 1981. Graft compatibility-incompatibility in higher plants. What's New in Plant Physiol 12:13-26.

Moore, R. 1983. Studies of vegetative compatibilityincompatibility in higher plants. IV. The development of tensile strength in a compatible an incompatible graft. Amer. J. Bot. 70:226-231.

Moore, R. and D.B. Walker. 1981. Studies of vegetative compatibility-incompatibility in higher plants I. A structure study of a compatible autograft in Sedum telephiodes (Crassulaceae). Amer. J. Bot. 68:820-830.

Oda, M. 1999. Grafting of vegetables to improve greenhouse production, p. 1-11. Extension bulletin-Food \& fertilizer technology center.

Oda, M., K. Tsuji, K. Ichmura, and H. Sasaki. 1994. Factors affecting the survival of cucumber plants grafted on pumpkin plants by horizontal grafting at the hypocotyl level. Bulletin of the National Research Institute of Vegetables, Ornamental Plants and Tea. Series A: Vegetables and Ornamental Plants. p. 51-60.

Scott, J. and R. Gardner. 2007. Breeding for resistance to fungal pathogens, p. 421-456. In: MK, R. and A. Mattoo (eds.). Genetic improvement of solanaceous crops. Science Publishers, Enfield, NH. 